Jurnal Ilmu Ilmu Agribisnis: Journal of Agribusiness Science, 9(3), Agustus 2021

\title{
TINGKAT KEPUASAN KONSUMEN TERHADAP PEMBELIAN MAKANAN PRODUK AYAM BAKAR ABMJ MELALUI E-COMMERCE GOJEK DI KOTA BANDAR LAMPUNG
}

\author{
(Customer Satisfaction on ABMJ Grilled Chicken Products Purchased through Gojek E-commerce \\ in Bandar Lampung)
}

Destia Rahmasanti, Yaktiworo Indriani, Wuryaningsih Dwi Sayekti

Jurusan Agribisnis, Fakultas Pertanian, Universitas Lampung, Jl. Prof. Dr. Soemantri Brodjonegoro No. 1

Bandar Lampung 35145, e-mail: yaktiworo.indriani@fp.unila.ac.id

\begin{abstract}
This research aims to determine the consumers' characteristics, the stages of decision making, and consumers satisfaction on buying ABMJ grilled chicken through Gojek e-commerce in Bandar Lampung. The location was determined purposively, in which samples were 65 people. The data were analyzed using descriptive analysis method, Customer Satisfaction Index (CSI), and Importance Performance Analysis (IPA). The research showed that the consumers who bought ABMJ through Gofood were mainly single women around 19-24 years old, had bachelor degree, and had monthly income around IDR2,600,000.00IDR3,500,000.00. The consumer's decision making process was conducted through the introduction of needs, information search, alternative evaluation, purchase decision, and post-purchase evaluation. Ease of purchase encouraged consumers to make transaction through Gofood and consumed ABMJ grilled chicken for their meals. Consumers acquired the resources and information by their friends who had consumed ABMJ grilled chicken. Price and advertisement in Gofood feature was highly considered by consumers. The consumers made purchases depending on the circumstances, so there was no planning before and more than three purchases made in the last three months. Consumers were satisfied and would still buy even if the price of the ABMJ grilled chicken increases. The value of CSI was 79.22\%; it showed that the customers had been completely satisfied. Based on the IPA analysis, customers valued that information clarity, photographic clarity, delivery time, and the safety of maintaining confidentiality of consumer's identity should be improved.
\end{abstract}

Key words: CSI, IPA, purchasing decision, satisfaction

\section{PENDAHULUAN}

Kemajuan di bidang teknologi dan informasi saat ini telah menciptakan e-business sebagai strategi baru bagi para pelaku usaha untuk mengembangkan bisnisnya. E-business mengubah era bisnis tradisional menjadi transaksi jual beli elektronik berbasis internet yang lazim disebut $e$ commerce. Indonesia merupakan pasar terbesar $e$ commerce di Asia Tenggara. Dilansir dari situs wartaekonomi.co.id yang dipublikasikan pada 19 Februari 2019, Indonesia merupakan pasar dengan pertumbuhan e-commerce yang menarik dari tahun ke tahun.

Saat ini, pemanfaatan e-business tidak hanya didominasi oleh unit berskala besar saja. Sudah banyak pelaku Usaha Kecil Menengah (UKM) yang mulai memanfaatkan e-business melalui $e$ commerce. Pemanfaatan e-commerce dapat memperoleh keuntungan strategis seperti terintegrasinya profil bisnis dari sisi eksternal dan internal, tumbuhnya jangkauan pasar yang semakin luas, meningkatnya relasi dan komunikasi dengan konsumen (Poorangi, Khin, Nikoonejad, dan Kardevani, 2013). Beberapa kerugian yang dapat timbul melalui pemanfaatan e-commerce untuk berbisnis, diantaranya kehilangan kesempatan bisnis karena gangguan pelayanan, pencurian informasi rahasia yang berharga dan kerugian lain yang tak terduga.

Salah satu rumah makan yang mencoba memanfaatkan peluang tersebut adalah Ayam Bakar Mbok Jum (ABMJ) yang cabang utamanya berada di Jl. Teuku Cik Ditro, Beringin Raya, Kemiling, Bandar Lampung dan terdapat 5 cabang lainnya yang tersebar di Kota Bandar Lampung. Rumah makan ABMJ sudah memasarkan produknya lewat offline sejak tahun 2014 dan memasarkan produknya melalui Gofood dan Grabfood pada tahun 2017. Gofood dan Grabfood merupakan sebuah fitur layanan online food delivery layaknya delivery order di sebuah rumah makan. Gofood merupakan salah satu fitur dari $e$ commerce Gojek, sedangkan Grabfood merupakan 
salah satu fitur dari e-commerce Grab. Dilansir dari idntimes.com yang dipublikasikan 12 April 2019, Gofood berhasil memimpin layanan pesan antar makanan secara online di Indonesia. Faktor yang menjadikan Gofood sebagai aplikasi pesan antar makan yang unggul menurut hasil riset IDN Times didasarkan pada brand identity yang lebih familiar atau lebih dikenali jika dibandingkan Grabfood.

Konsumen lebih banyak melakukan pemesanan melalui Gofood dibandingkan dengan Grabfood. Pemesanan melalui Gofood rata-rata per hari per cabang sebanyak 40 sampai 50 pesanan, sedangkan Grabfood hanya 15 sampai 25 pesanan. Menurut salah satu karyawan ABMJ, alasan banyaknya pembelian melalui Gofood dikarenakan Gofood sering memberikan voucher gratis ongkir kepada penggunanya jika dibandingkan dengan Grabfood. Oleh karena itu, penelitian ini hanya meneliti pada Gofood yang lebih banyak konsumennya.

Tingkat persaingan antar pelaku usaha yang menggunakan Gofood sebagai strategi pemasaran, menjadi motivasi bagi para pelaku usaha untuk dapat mempertahankan kepuasan konsumen dengan meningkatkan kualitas pelayanan atau yang dikenal dengan e-service quality dalam pemasaran online dan mempertahankan kualitas makanan. Kehadiran toko offline yang berkembang beriringan dengan toko online membuat rumah makan ABMJ dihadapkan pada permasalahan baru yaitu sulitnya mempertahankan kualitas pelayanan dan kualitas makanan yang sama, karena adanya Gofood sebagai perantara produsen dan konsumen.

Konsumen akan melakukan proses evaluasi terhadap konsumsi yang telah dilakukannya. Proses ini disebut sebagai proses evaluasi alternatif pasca pembelian atau pasca konsumsi. Hasil dari proses pasca konsumsi adalah konsumen puas atau tidak puas terhadap produk yang dikonsumsinya. Menurut Sumarwan (2018), kepuasan akan mendorong konsumen membeli dan mengonsumsi ulang produk tersebut, sebaliknya perasaan yang tidak puas akan menyebabkan konsumen kecewa dan menghentikan pembelian kembali dalam mengonsumsi produk tersebut. Berdasarkan uraian tersebut, maka tujuan penelitian ini adalah mengetahui karakteristik konsumen, mengetahui proses pengambilan keputusan konsumen, menganalisis tingkat kepuasan konsumen, dan menganalisis kinerja e-services quality Gofood serta kualitas makanan ABMJ.

\section{METODE PENELITIAN}

Metode yang digunakan pada penelitian ini adalah survei. Penelitian dilakukan pada enam cabang rumah makan ABMJ yang tersebar di Kota Bandar Lampung. Penentuan lokasi dilakukan secara sengaja (purposive) dengan pertimbangan melihat dari fitur Gofood pada aplikasi Gojek bahwa rumah makan ABMJ merupakan salah satu rumah makan yang cukup digemari dan dipercaya oleh konsumen dengan rating penilaian sebesar 4,6 sampai 4,7 dari total rating 5 pada setiap cabangnya, sehingga dapat memudahkan dalam mencari konsumen. Pengambilan data dilakukan dari bulan Februari sampai Maret 2020.

Jenis data yang digunakan adalah data primer dan data sekunder. Data primer pada penelitian ini berasal dari proses menyebarkan kuesioner yang telah diuji validitas dan reliabilitasnya melalui google form kepada konsumen ABMJ. Data sekunder diperoleh dari literatur, artikel, jurnal, serta situs di internet yang berkenaan dengan penelitian yang dilakukan.

Pengambilan sampel dilakukan dengan metode non-probability sampling yaitu quota sampling. Quota sampling adalah teknik untuk menentukan sampel dari populasi yang mempunyai ciri-ciri tertentu sampai jumlah (kuota) yang diinginkan (Sugiyono 2012). Karakteristik sampel dalam penelitian ini adalah konsumen yang pernah membeli ayam bakar ABMJ melalui Gofood dan berdomisili di Kota Bandar Lampung. Penentuan jumlah sampel pada penelitian ini, merujuk pada rumus (Arikunto 2010) sebagai berikut

$\mathrm{n}=25 \% \times \mathrm{x}$

$$
\begin{aligned}
& \text { Keterangan : } \\
& \mathrm{n} \quad=\text { Ukuran sampel } \\
& \mathrm{N} \quad=\text { Ukuran populasi }
\end{aligned}
$$

Arikunto (2010) menyatakan jika populasi penelitian kurang dari 100 sebaiknya diambil semuanya, namun jika populasi penelitian berjumlah lebih dari 100 maka sampel dapat diambil antara 10-15 persen atau 20-25 persen atau lebih. Berdasarkan hasil wawancara total konsumen seluruh cabang ABMJ sebanyak 260 orang per hari. Perhitungan sampel dengan menggunakan rumus tersebut, maka diperoleh jumlah sampel konsumen yang pernah membeli 
ayam bakar ABMJ melalui Gofood sebanyak 65 orang.

Uji validitas dan reliabilitas kuesioner dilakukan terlebih dahulu pada 30 konsumen. Setelah hasilnya valid dan reliabel, maka kuesioner dapat digunakan untuk analisis kepuasan konsumen. Berdasarkan hasil uji validitas, semua atribut $e$ services quality dan kualitas makanan memiliki $\mathrm{r}$ hitung >0,361 yang artinya semua atribut dalam penelitian dapat digunakan (valid). Untuk uji reliabel, didapatkan hasil nilai alpha tingkat kepentingan 0,911 dan tingkat kinerja 0,930 yang artinya nilai Alpha Cronbach $>0,60$ sehingga semua atribut reliabel atau dapat dipercaya (Arikunto 2010).

Analisis deskriptif digunakan untuk menjawab tujuan pertama dan kedua yaitu karakteristik konsumen dan proses keputusan pembelian produk ABMJ melalui Gofood. Tujuan analisis deskriptif untuk membuat deskripsi, gambaran atau lukisan secara sistematis, faktual dan akurat mengenai fakta-fakta, sifat-sifat serta hubungan antar fenomena yang diselidiki. Hasil data kuesioner mengenai keputusan pembelian dan karakteristik konsumen dikelompokkan berdasarkan jawaban yang sama dan disajikan dalam bentuk tabulasi deskriptif. Karakteristik konsumen dilihat berdasarkan usia, jenis kelamin, status pernikahan, tingkat pendidikan, dan pendapatan. Proses pengambilan keputusan adalah sebuah tahapan konsumen dalam membeli ayam bakar ABMJ yang terdiri dari beberapa tahap yaitu pengenalan kebutuhan, pencarian informasi, evaluasi alternatif, keputusan pembelian dan perilaku pasca pembelian.

Indikator kepuasan dan kinerja dilihat berdasarkan $e$-services quality dan kualitas makanan. Atribut $e$ services quality terdiri dari information; kejelasan informasi produk, dan kejelasan informasi transaksi, easy of use; kemudahan pemesanan, kemudahan pembayaran, dan kemudahan pembatalan, website design; kejelasan foto produk, dan tingkat kemenarikan fitur secara visual, reliability; ketepatan waktu pengiriman dan ketepatan produk yang dipesan, serta security/ privacy; keamanan dalam bertransaksi, dan keamanan dalam menjaga kerahasiaan identitas. Atribut kualitas makanan ABMJ terdiri dari warna, porsi, bentuk, temperatur, tekstur, aroma, tingkat kematangan dan rasa.

Analisis tingkat kepuasan konsumen diukur dengan menggunakan analisis Customer
Satisfaction Index (CSI). Analisis CSI adalah sebuah angka yang menyatakan seberapa besar tingkat kepuasan konsumen akan produk tertentu. Terdapat empat tahapan dalam menilai kepuasan melalui analisis CSI. Pertama adalah menentukan Mean Important Score (MIS) dan Mean Performance Score (MPS), kedua Weighting Factor (WF), ketiga Weighted Score (WS), keempat Weighted Total (WT), dan kelima Customer Satisfaction Index (CSI) (Aritonang 2005). Tingkat kepuasan konsumen secara keseluruhan dapat dilihat dari kriteria tingkat kepuasan konsumen yaitu sangat tidak puas $(0,00-0,20)$, tidak puas $(0,21-0,40)$, cukup puas $(0,41-0,60)$, puas $(0,61-0,80)$, dan sangat puas (0,81-1,00) (Supranto 2006). Setelah diketahui nilai CSI, selanjutnya dilakukan analisis Importance Performance Analysis (IPA) untuk mengetahui keadaan masing-masing atribut $e$ service quality Gofood dan kualitas makanan ABMJ ditinjau dari segi kinerja dan kepentingannya.

Analisis Importance Performance Analysis (IPA) merupakan suatu metode yang digunakan untuk mengukur atribut-atribut dari tingkat kepentingan dengan tingkat kinerja yang diharapkan konsumen dan sangat berguna bagi pengembangan program strategi pemasaran yang efektif (Simamora 2002). Analisis IPA digunakan untuk menggambarkan kinerja (performance) yang dipersepsikan oleh konsumen dalam bentuk diagram kartesius yang digunakan dalam menentukan kuadran yang terdapat pada analisis Importance and Performance Analysis (IPA). Kuadran pada analisis IPA terdiri dari kuadran I (prioritas utama), kuadran II (pertahankan prestasi), kuadran III (prioritas rendah) dan kuadran IV (kinerja berlebih). Hal yang perlu diperhatikan bahwa koordinat titik tengah kuadran mengacu pada grand mean, yakni rata-rata semua atribut pada bagian kepentingan dan rata-rata semua atribut pada bagian kinerja.

\section{HASIL DAN PEMBAHASAN}

\section{Karakteristik Konsumen}

Konsumen ayam bakar ABMJ sebagian besar berusia antara 19-24 tahun (57\%) dan berjenis kelamin perempuan $(52 \%)$. Hasil penelitian ini serupa dengan temuan Sulfiana, Murniati, dan Indriani (2018), hasil penelitian didapatkan bahwa sebagian besar konsumen lele terbang di Rumah Makan Sambal Lalap juga berusia antara 19-24 tahun, karena dianggap bahwa kelompok umur ini 
sudah memiliki banyak informasi mengenai produk yang akan dikonsumsi serta berjenis kelamin wanita, karena dianggap wanita lebih selektif dalam proses pembelian. Status pernikahan konsumen adalah lajang (55\%) dengan pendidikan terakhir Strata 1 (43\%). Sebagian besar pekerjaan konsumen adalah pegawai swasta (48\%) dengan rentang pendapatan per bulan sebesar Rp2.600.000,00-Rp3.500.000,00 (43\%). Menurut Sumarwan (2018), jumlah pendapatan menggambarkan besarnya daya beli konsumen. Daya beli akan menggambarkan banyaknya produk dan jasa yang dapat dibeli dan dikonsumsi oleh seorang konsumen dan anggota keluarganya.

\section{Proses Pengambilan Keputusan}

Proses pengambilan keputusan dalam pembelian ayam bakar ABMJ melalui Gofood dilakukan melalui tahapan pengenalan kebutuhan, pencarian informasi, evaluasi alternatif, keputusan pembelian dan evaluasi pasca pembelian. Pada tahap pengenalan kebutuhan, sebagian besar motivasi utama konsumen melakukan pembelian, karena kemudahan pembelian (54\%). Dengan adanya fitur Gofood, konsumen tidak perlu datang dan mengantre di restoran untuk mendapatkan produk yang ingin dibelinya, adanya Gofood dapat memudahkan konsumen karena berbagai macam jenis makanan sudah tersedia di dalam Gofood. Menurut Hartono (2007), akses yang tidak berbelit-belit dan sederhana menjadikan nilai tambah untuk meningkatkan persepsi kemudahan pembelian melalui e-commerce bagi pengguna suatu teknologi. Konsumen bertujuan membeli makanan untuk makanan sendiri (86\%), sedangkan sisanya bertujuan untuk makanan di acara tertentu.

Pada tahap pencarian informasi, sebagian besar konsumen memperoleh sumber informasi tentang produk ayam bakar ABMJ di Gofood melalui teman mereka (54\%). Hasil penelitian ini sejalan dengan hasil penelitian Basith dan Fadhilah (2018) yang menyatakan sebagian besar konsumen McDonald's di Jatiasih Bekasi memperoleh informasi melalui teman, karena konsumen biasanya akan lebih mempercayai orang-orang terdekatnya dalam mengonsumsi barang dan jasa. Teman dianggap paling memengaruhi konsumen dalam proses pembelian (58\%). Hal ini terkait dengan karakteristik konsumen yang didapatkan oleh peneliti kebanyakan adalah pekerja swasta, wiraswasta dan mahasiswa yang tentunya akan banyak melakukan interaksi baik dengan teman kampus, mitra kantor maupun relasi bisnis, sehingga informasi mengenai produk ayam bakar ABMJ sangat mungkin menyebar melalui interaksi tersebut.

Pertimbangan awal konsumen dalam membeli produk ayam bakar ABMJ di Gofood adalah harga (63\%) dan sisanya konsumen menyatakan bahwa rasa menjadi pertimbangan terakhir setelah harga. Hasil penelitian ini sesuai dengan temuan Yulita, Lestari, dan Haryono (2014) dari penelitiannya pada konsumen susu cair dalam kemasan KPBS yang menyatakan bahwa sebagian besar konsumennya membeli dengan pertimbangan awal harga, karena harga susu cair yang ditawarkan oleh KPBS terjangkau. Sebagian besar konsumen menyatakan iklan yang ada di fitur Gofood sangat memengaruhi proses pembelian (63\%), sedangkan sisanya (37\%) konsumen merasa tidak terpengaruh. Iklan ditujukan untuk menginformasikan suatu produk barang atau jasa kepada khalayak untuk dapat mengarahkan konsumen membeli dan mengubah sikap agar sesuai dengan apa yang diinginkan oleh pengiklan (Junaedi 2013).

Sebanyak (43\%) konsumen melakukan pembelian tergantung situasi, yang artinya konsumen ingin membeli produk tersebut, namun ada beberapa pertimbangan yang harus konsumen pikirkan dahulu sebelum membeli produk tersebut. Frekuensi pembelian dilakukan lebih dari tiga kali dalam 3 bulan terakhir (34\%). Hal ini menunjukkan bahwa konsumen setia dalam membeli produk ayam bakar ABMJ, sehingga dilakukan pembelian lebih dari satu kali. Konsumen dikatakan setia atau loyal apabila pelanggan tersebut menunjukkan perilaku pembelian secara teratur atau terdapat suatu kondisi, dimana mewajibkan pelanggan membeli paling sedikit dua kali dalam selang waktu tertentu (Griffin 2005).

Konsumen menyatakan puas terhadap pembelian produk ayam bakar ABMJ melalui Gofood (55\%). Konsumen akan tetap melakukan pembelian $(55 \%)$, walaupun harga produk mengalami kenaikan, sedangkan sisanya (45\%) konsumen akan tetap membeli, namun jarang-jarang dalam pembeliannya. Hal ini sejalan dengan penelitian Putri, Sayekti, dan Rangga (2019) pada konsumen rumah tangga dalam membeli sayuran di Desa Gisting Atas yang menyatakan bahwa konsumen akan tetap membeli apabila harga sayur mengalami kenaikan, karena konsumen mengonsumsi sayuran sebagai pelengkap menu rumah tangga. 


\section{Customer Satisfaction Index (CSI)}

Tabel 1, didapatkan nilai Weighted Score tertinggi dimensi produk berada pada atribut rasa yaitu sebesar 0,255 sedangkan nilai Weighted Score terendah berada pada atribut warna ayam bakar yaitu sebesar 0,187. Nilai Weighted Score tertinggi pada dimensi e-services quality, berada pada kemudahan pemesanan, sedangkan nilai Weighted Score terendah berada pada atribut tingkat kemenarikan fitur secara visual. Hasil perhitungan Customer Satisfaction Index (CSI) pembelian produk ayam bakar ABMJ melalui Gofood didapatkan nilai sebesar 79,22 persen. Nilai Customer Satisfaction Index (CSI) berada pada rentang skala $0,61-0,80$, ini menunjukkan bahwa indeks kepuasan konsumen yang melakukan pembelian produk ayam bakar ABMJ melalui Gofood berada pada kriteria puas.

Pada perhitungan tingkat kepuasan dimensi kualitas makanan, konsumen memberikan nilai kepuasan tertinggi pada atribut rasa, karena atribut rasa yang enak pada produk ayam bakar ABMJ yang menjadi daya tarik konsumen. Hal ini sejalan dengan penelitian yang dilakukan Doloksaribu, Indriani, dan Kalsum (2016) pada konsumen rumah makan Bebek Belur di Kota Bandar Lampung dalam mengonsumsi produk olahan bebek yang menyatakan bahwa atribut rasa memiliki tingkat kepuasan yang tinggi dibandingkan poin-poin pada atribut lainnya.
Atribut kualitas makanan dengan kepuasan terendah berada pada warna ayam bakar. Warna ayam bakar ABMJ yang ditawarkan sama saja dengan ayam bakar pada umumnya, sehingga konsumen tidak memberikan kepuasan tinggi pada atribut ini. Nilai kepuasan tertinggi pada dimensi e-services quality, berada pada atribut kemudahan pemesanan. Kemudahan pemesanan melalui Gofood memberikan kepuasan bagi konsumen, karena konsumen tidak perlu repot-repot datang ke rumah makan untuk membeli makanan yang diinginkan. Nilai kepuasan terendah pada dimensi e-services quality, berada pada atribut tingkat kemenarikan fitur secara visual. Hal ini dapat dilihat pada fitur Gofood, desain kemenarikan fitur secara visual masih dianggap sederhana bagi konsumen, sehingga belum dapat memberikan kepuasan yang diinginkan.

Konsumen yang melakukan pembelian produk ayam bakar ABMJ melalui Gofood memberikan penilaian yang positif terhadap atribut-atribut. Sikap positif yang diberikan konsumen terlihat bahwa konsumen merasa puas terhadap kinerja yang diberikan terhadap pembelian produk ayam bakar ABMJ melalui Gofood ini. Hasil penelitian sejalan dengan penelitian Pratama, Indriani, dan Endaryanto (2017), bahwa nilai Customer Satisfaction Index (CSI) pada konsumsi makanan pecel lele di Kota Bandar Lampung sebesar 70,50 persen yang berarti bahwa konsumen telah merasa puas.

Tabel 1. Perhitungan Customer Satisfaction Index (CSI) pembelian produk ayam bakar ABMJ melalui Gofood

\begin{tabular}{|c|c|c|c|c|c|c|}
\hline Komponen & Dimensi & Atribut & MIS & WF & MPS & WS \\
\hline Kualitas & Produk & Warna & 4,462 & 0,052 & 3,600 & 0,187 \\
\hline \multirow[t]{7}{*}{ Makanan } & & Porsi & 4,169 & 0,048 & 3,892 & 0,189 \\
\hline & & Bentuk & 4,462 & 0,052 & 3,923 & 0,204 \\
\hline & & Temperatur & 4,323 & 0,050 & 3,815 & 0,192 \\
\hline & & Tekstur & 4,492 & 0,052 & 3,923 & 0,205 \\
\hline & & Aroma & 4,462 & 0,052 & 4,031 & 0,209 \\
\hline & & Tingkat kematangan & 4,692 & 0,055 & 4,123 & 0,225 \\
\hline & & Rasa & 4,723 & 0,055 & 4,646 & 0,255 \\
\hline \multirow{11}{*}{$\begin{array}{l}\text { Kualitas } \\
\text { e-services }\end{array}$} & Information & Kejelasan informasi produk & 4,538 & 0,053 & 3,846 & 0,203 \\
\hline & & Kejelasan informasi transaksi & 4,415 & 0,051 & 3,985 & 0,205 \\
\hline & Easy of use & Kemudahan pemesanan & 4,600 & 0,054 & 4,277 & 0,229 \\
\hline & & Kemudahan pembayaran & 4,615 & 0,054 & 4,231 & 0,227 \\
\hline & & Kemudahan pembatalan & 4,477 & 0,052 & 3,738 & 0,195 \\
\hline & Website design & Kejelasan foto produk & 4,646 & 0,054 & 3,569 & 0,193 \\
\hline & & Tingkat kemenarikan fitur secara visual & 4,369 & 0,051 & 3,754 & 0,191 \\
\hline & Reliability & Ketepatan waktu pengiriman & 4,692 & 0,055 & 3,800 & 0,207 \\
\hline & & Ketepatan produk yang dipesan & 4,646 & 0,054 & 4,062 & 0,220 \\
\hline & Security/Privacy & Keamanan dalam bertransaksi & 4,646 & 0,054 & 4,046 & 0,219 \\
\hline & & Keamanan dalam menjaga kerahasiaan identitas & 4,615 & 0,054 & 3,938 & 0,211 \\
\hline Total Skor & & & 86,046 & & & 3,961 \\
\hline CSI $(\%)$ & & & & & & 79,221 \\
\hline
\end{tabular}




\section{Tingkat Kesesuaian dan Importance Performance Analysis (IPA)}

Tingkat kesesuaian adalah hasil perbandingan skor tingkat kinerja dan skor kepentingan atribut dari konsumen. Tingkat kesesuaian ini akan menentukan prioritas peringkatan faktor yang memenuhi kepuasan konsumen (Riduwan 2010). Tingkat kesesuaian pembelian makanan produk ayam bakar ABMJ melalui Gofood berkisar antara 76,821 persen-98,371 persen. Rata-rata tingkat kesesuaian kepentingan dan kinerja sebesar 87,395 persen. Nilai rata-rata tingkat kesesuaian yang didapatkan disajikan pada Tabel 2.

Pada kualitas makanan, tingkat kesesuaian tertinggi adalah atribut rasa dengan nilai sebesar 98,371 persen karena rasa ayam bakar yang dirasakan enak dan sesuai di lidah konsumen. Atribut yang memiliki tingkat kesesuaian tertinggi kedua pada kualitas makanan adalah porsi, yaitu sebesar 93,358 persen karena porsi yang diterima konsumen pas dan sesuai dengan harapan konsumen. Atribut yang memiliki tingkat kesesuaian tertinggi ketiga pada kualitas makanan adalah aroma, dengan nilai sebesar 90,345 persen karena menurut konsumen aroma ayam bakar ABMJ yang dihidangkan sedap dan menggugah selera.

Pada kualitas e-services, tingkat kesesuaian tertinggi adalah atribut kemudahan pemesanan dengan tingkat kesesuaian 92,977 persen, karena pembelian melalui Gofood menyediakan fasilitas bagi konsumen untuk bebas memilih menu dan memberikan pesan tambahan pada fitur catatan tambahan. Atribut yang memiliki tingkat kesesuaian tertinggi kedua yaitu kemudahan pembayaran yaitu sebesar 91,667 persen. Hal ini didasari dengan adanya fitur pilihan metode pembayaran, sehingga konsumen dapat menyesuaikan pilihan metode pembayaran dengan sumber daya yang dimiliki. Atribut yang memberikan tingkat kesesuaian tertinggi ketiga di kualitas e-services adalah ketepatan produk yang dipesan dengan nilai sebesar 87,417 persen, ini berarti bahwa produk yang diterima konsumen sesuai dengan yang dipesan melalui layanan Gofood.

Berdasarkan nilai rata-rata tingkat kesesuaian yang didapatkan pada Tabel 2, pembelian makanan produk ayam bakar ABMJ melalui Gofood berada pada kategori tinggi, yang artinya konsumen telah merasa sangat puas terhadap kinerja yang telah dilakukan dan perlu dipertahankan guna mempertahankan kepuasan konsumen. Data pada Tabel 2 menunjukkan bahwa nilai rata-rata tingkat kepentingan adalah sebesar 4,529 dan nilai ratarata tingkat kinerja adalah 3,958. Kedua nilai tersebut menjadi garis tengah pada diagram kartesius Importance Performance Analysis (IPA). Diagram kartesius Importance Performance Analysis (IPA) dapat dilihat pada Gambar 1.

Tabel 2. Rata-rata tingkat kepentingan, tingkat kinerja, dan tingkat kesesuaian rumah makan

\begin{tabular}{|c|c|c|c|c|c|}
\hline Komponen & Dimensi & Atribut & MIS & MPS & $\begin{array}{c}\text { Tingkat } \\
\text { Kesesuaian }(\%)\end{array}$ \\
\hline Kualitas & Produk & Warna & 4,462 & 3,600 & 80,690 \\
\hline \multirow[t]{7}{*}{ Makanan } & & Porsi & 4,169 & 3,892 & 93,358 \\
\hline & & Bentuk & 4,462 & 3,923 & 87,931 \\
\hline & & Temperatur & 4,323 & 3,815 & 88,256 \\
\hline & & Tekstur & 4,492 & 3,923 & 87,329 \\
\hline & & Aroma & 4,462 & 4,031 & 90,345 \\
\hline & & Tingkat kematangan & 4,692 & 4,123 & 87,869 \\
\hline & & Rasa & 4,723 & 4,646 & 98.371 \\
\hline \multirow{11}{*}{$\begin{array}{l}\text { Kualitas } \\
\text { e-services }\end{array}$} & Information & Kejelasan informasi produk & 4,538 & 3,846 & 84,746 \\
\hline & & Kejelasan informasi transaksi & 4,415 & 3,985 & 90,244 \\
\hline & Easy of use & Kemudahan pemesanan & 4,600 & 4,277 & 92,977 \\
\hline & & Kemudahan pembayaran & 4,615 & 4,231 & 91,667 \\
\hline & & Kemudahan pembatalan & 4,477 & 3,738 & 83,505 \\
\hline & Website design & Kejelasan foto produk & 4,646 & 3,569 & 76,821 \\
\hline & & Tingkat kemenarikan fitur secara visual & 4,369 & 3,754 & 85,915 \\
\hline & Reliability & Ketepatan waktu pengiriman & 4,692 & 3,800 & 80,984 \\
\hline & & Ketepatan produk yang dipesan & 4,646 & 4,062 & 87,417 \\
\hline & Security/ Privacy & Keamanan dalam bertransaksi & 4,646 & 4,046 & 87,068 \\
\hline & & Keamanan dalam menjaga kerahasiaan identitas & 4,615 & 3,938 & 85,333 \\
\hline Rata-rata & & & 4,529 & 3,958 & 87,395 \\
\hline
\end{tabular}




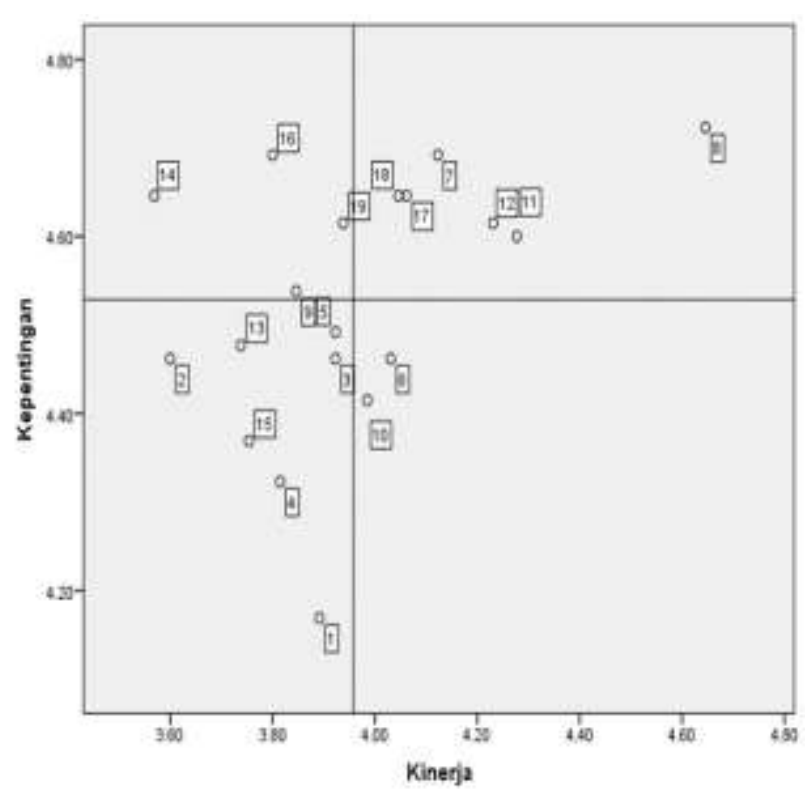

Gambar 1. Diagram IPA kepuasan konsumen terhadap pembelian makanan produk ayam bakar ABMJ melalui Gofood

Keterangan:

1 = Warna

2 = Porsi

3 = Bentuk

$4=$ Temperatur

$5=$ Tekstur

6 = Aroma

7 = Tingkat kematangan

8 = Rasa

$9=$ Kejelasan informasi produk

$10=$ Kejelasan informasi transaksi

$11=$ Kemudahan pemesanan

$12=$ Kemudahan pembayaran

$13=$ Kemudahan pembatalan

$14=$ Kejelasan foto produk

$15=$ Tingkat kemenarikan fitur secara visual

$16=$ Ketepatan waktu pengiriman

$17=$ Ketepatan produk yang dipesan

$18=$ Keamanan dalam bertransaksi

$19=$ Keamanan dalam menjaga kerahasiaan identitas

Atribut yang berada pada kuadran I (prioritas utama) adalah kejelasan informasi produk, kejelasan foto produk, ketepatan waktu pengiriman, dan keamanan dalam menjaga kerahasiaan identitas. Atribut ini merupakan atribut yang dianggap mempunyai pengaruh besar terhadap kepuasan konsumen, termasuk unsurunsur yang dianggap sangat penting bagi konsumen, namun perusahaan belum melaksanakannya dengan maksimal, sehingga dapat membuat konsumen kecewa atau tidak puas.
Kuadran II menunjukkan faktor atau atribut yang dianggap penting oleh konsumen dan sudah berhasil dilakukan oleh rumah makan, sehingga memberikan tingkat kepuasan yang temperatur tinggi terhadap konsumen. Atribut yang termasuk dalam kuadran II (pertahankan prestasi) adalah tingkat kematangan, rasa, kemudahan pemesanan, kemudahan pembayaran, ketepatan produk yang dipesan, serta keamanan dalam bertransaksi. Hasil penelitian ini sejalan dengan temuan Triani, Hudoyo, dan Suryani (2016) dari penelitiannya pada konsumen dua rumah makan olahan bebek di Kota Bandar Lampung yang menyatakan bahwa atribut rasa berada pada kuadran ini.

Atribut yang termasuk ke dalam kuadran III (prioritas rendah) adalah warna, porsi, bentuk, temperatur, tekstur, kemudahan pembatalan, dan tingkat kemenarikan fitur secara visual. Kuadran ini menunjukkan faktor atau atribut yang dianggap kurang penting bagi konsumen dan kinerja rumah makan yang rendah, sehingga dianggap kurang memuaskan bagi konsumen. Sementara atribut yang terdapat pada kuadran IV (berlebihan) adalah aroma dan kejelasan informasi transaksi. Kuadran ini menunjukkan faktor atau atribut yang dianggap kurang penting bagi konsumen, tetapi kinerjanya secara berlebihan oleh restoran, sehingga kemungkinan mengakibatkan pemborosan.

\section{KESIMPULAN}

Konsumen yang melakukan pembelian produk ayam bakar ABMJ melalui Gofood sebagian besar berusia 19-24 tahun (57\%), perempuan yang masih lajang $(52 \%)$, berpendidikan Strata 1 (43\%), bekerja sebagai pegawai swasta $(48 \%)$, dengan pendapatan sebesar Rp2.600.000,00Rp3.500.000,00 per bulan (43\%). Kemudahan pembelian mendorong konsumen melakukan pembelian melalui Gofood dan mengkonsumsi ayam bakar ABMJ sebagai makanan sendiri. Sumber dan informasi yang didapatkan konsumen berasal dari teman yang pernah mengonsumsi ayam bakar ABMJ. Atribut harga dan iklan yang ada di fitur Gofood sangat dipertimbangkan oleh konsumen. Konsumen melakukan pembelian tergantung keadaan atau tidak ada perencanaan sebelumnya dan pembelian lebih dari 3 kali dalam 3 bulan terakhir. Setelah melakukan pembelian konsumen merasa puas dan tetap akan membeli walaupun harganya naik. Nilai kepuasan konsumen yang didapatkan berada pada kategori puas, yang berarti kualitas makanan dan e-services sudah memuaskan konsumen. Kinerja ABMJ berada pada kuadran pertama (prioritas utama), 
artinya atribut perlu diperbaiki seperti perlunya kejelasan informasi produk, kejelasan foto produk, ketepatan waktu pengiriman dan keamanan dalam menjaga kerahasiaan identitas konsumen.

\section{DAFTAR PUSTAKA}

Axel JH. 2019. Go-Food, Layanan Online Pengantar Makanan Terbesar di Indonesia. https://www.idntimes.com/business/economy/ axel-harianja/go-food-layanan-online-pengant ar-makanan-terbesar-di-indonesia/full. Januari 2020].

Arikunto S. 2010. Prosedur Penelitian Suatu Pendekatan Praktik. Rineka Cipta. Jakarta.

Aritonang LR. 2005. Kepuasan Konsumen. Gramedia. Jakarta.

Basith A dan Fadhilah F. 2018. Analisis faktorfaktor yang mempengaruhi keputusan pembelian produk pada McDonald's di Jatiasih Bekasi. Jurnal Manajemen dan Organisasi (JMO), 9 (3): 191-202. https:// journal.ipb.ac.id/index.php/jmo/article/view/2 8224/18005. [16 April 2020].

Doloksaribu YM, Indriani Y, dan Kalsum U. 2016. Sikap, kepuasan, dan loyalitas konsumen produk olahan bebek (Kasus di Rumah Makan Bebek Belur di Kota Bandar Lampung). Jurnal Ilmu Ilmu Agribisnis, 4 (3): 335-341. https://jurnal.fp.unila.ac.id/index.php/JIA/artic le/download/1509/1363. [29 Juli 2020].

Griffin J. 2005. Customer Loyalty: Menumbuhkan dan Mempertahankan Kesetiaan Pelanggan. Erlangga. Jakarta.

Hartono J. 2007. Sistem Informasi Keperilakuan. Andi Offset. Yogyakarta.

Junaedi F. 2013. Komunikasi Massa Pengantar Teoritis. Santusta.Yogyakarta.

Kotler P dan Keller KL. 2016. Marketing Management. Edisi 15. Pearson Prentice Hall. England.

Poorangi MM, Khin EW, Nikoonejad S, dan Kardevani A. 2013. E- commerce Adoption in Malaysian Small and Medium Enterprises Practitioner Firms: A revisit on Rogers' model. Anais da Academia Brasileira de Ciências, 85 (4): 1593-1604. http://www. scielo.br/pdf /aabc/v85n4/0001-3765-aabc-8504-1593.pdf. [13 Januari 2020].

Pratama DY, Indriani Y, dan Endaryanto T. 2017. Sikap dan kepuasan konsumen terhadap konsumsi pecel lele di dua rumah makan Kota Bandar Lampung. Jurnal Ilmu Ilmu Agribisnis,5(12):200205.http://jurnal.fp.unilaa c.id/index.php/JIA/article/download/\%201659 1\%201485.[11 Juli 2020].

Putri DP, Sayekti WD, dan Rangga KK. 2019. Pengambilan keputusan dalam pemilihan sayuran dan pola konsumsi sayuran rumah tangga petani sayuran di Desa Gisting Atas Kecamatan Gisting Kabupaten Tanggamus. Jurnal Ilmu Ilmu Agribisnis, 7 (3): 420-427. http://jurnal.fp.unila.ac.id/index.php/JIA/articl e/download/3782/2783. [12 Juli 2020].

Rahayu N. 2019. Pertumbuhan E-commerce Pesat di Indonesia. https://www.wartaekonomi.co.id /read216302/pertumbuhan-e-commerce-pesatdi- indonesia.html. [15 Oktober 2019].

Riduwan. 2010. Skala Pengukuran VariabelVariabel Penelitian. Alfabeta. Bandung.

Simamora B. 2002. Panduan Riset Perilaku Konsumen. PT. Gramedia Pustaka Utama. Jakarta.

Sugiyono. 2012. Metode Penelitian Kuantitatif Kualitatif dan $R$ dan $D$. Alfabeta. Bandung.

Sulfiana WN, Murniati K, dan Indriani Y. 2018. Sikap dan kepuasan konsumen terhadap paket menu lele terbang, kaitannya dengan bauran pemasaran di Rumah Makan Lalap Bandar Lampung. Jurnal Ilmu Ilmu Agribisnis, 6 (1): 7278.https://jurnal.fp.unila.ac.id/index.php/JI A/article/view/2501/2185. [15 Maret 2020].

Sumarwan U. 2018. Perilaku Konsumen. Edisi 2. Ghalia Indonesia. Bogor.

Supranto. 2006. Mengukur Tingkat Kepuasan Konsumen atau Konsumen. Rineka Cipta. Jakarta.

Triani TL, Hudoyo A, dan Suryani A. 2016. Identifikasi atribut kepuasan dan pelayanan rumah makan: studi kasus pada dua rumah makan olahan bebek di Kota Bandar Lampung. Jurnal Ilmu Ilmu Agribisnis, 4 (4): 398405.https://jurnal.fp.unila.ac.id/index.php/ JIA/article/download/1522/1376.[27Juli2020].

Yulita M, Lestari DA, dan Haryono D. 2014. Tingkat Kepuasan dan loyalitas konsumen produk susu cair dalam kemasan Koperasi Peternakan Bandung Selatan (KBPS) di Kota Bandar Lampung. Jurnal Ilmu Ilmu Agribisnis, 2 (2): 158-165. http:// jurnal.fp.unila.ac.id/index.php/JIA/article/dow nload/741/682. [13 Juli 2020]. 